\title{
Utilizing Motive of Children Literature Collection in Children Reading Room
}

\author{
Gustiana Sabarina, Haria Saputri Wahyuni, Rahmat Alifin Valentino \\ Postgraduate Program, Master of Communication Study, Universitas Padjadjaran \\ gustiana17001@mail.unpad.ac.id
}

\begin{abstract}
Children reading room in West Java Regional Library and Archives Agency (BAPUSIPDA: Badan Perpustakaan dan Kearsipan Daerah Jawa Barat) is an agency library service that provides children books collection. The collection frequently used by children in the agency children reading room is a collection of literary books. This study looked for to investigate the motive of the use of literature collection by children in the agency children reading room. The purpose of this research was to know the utilization motive of the collection in the agency children reading room that refers to the action in the future and the past. This research was based on the theory of phenomenology. This research is qualitative research with phenomenology approach. This research selected five children librarian in the agency children reading room who were still elementary students (SD: Sekolah Dasar). The results of this research were (1) the motive of the utilization of children literature collection in the children reading room related to future actions are to increase knowledge and utilize the collection as reference for school and exam, the ease in comprehending the collection of fiction books and the desire to explore the inspirational values contained in the reading and character of fiction books; (2) the motive of the utilization of children literature collection in the children reading room related to past actions are the completeness of the collection that makes the children have more choices of reading material, to actualize the hobby in reading, the passion in reading the collection with varied illustrations and colors and the comfort of the room that makes the children become comfortable.
\end{abstract}

Keywords--Motive, collection utilization, children literature, reading room service

\section{INTRODUCTION}

West Java Regional Library and Archives Agency provides a variety of services; one of which is children reading room service. Children reading room provides a collection of children books that is situated in West Java Regional Library and Archives Agency. The books are divided into categories and organized on shelves according to the themes of book and collection. The types of fiction book are folklore, fairy tale, fable and comic. The types of nonfiction book are elementary to junior high school textbooks, encyclopedia, dictionary, religious book, ethical book and moral book. The magazine's collection includes Bobo magazine and Kids geography. On the wall of West Java Regional Library and Archives, there is a painting of Jaka Tarub from West Java that adorns the children reading room wall, which embraces the attracting impression and gives a sense of comfort for children to read, learn and play.

West Java Regional Library and Archives Agency is a library that is expected to provide a good means for the community especially for children readers, in which they can utilize the library in order to meet the information needs. This is in accordance with the vision of the library that is: "Library and Archives serves as a reliable source of information for the sake of making West Java people more intelligent."

Based on the statistical result collected by West Java Regional Library and Archives Agency in 2015 regarding the daily books read is depicted below. 
Table 1.1

Statistics of Monthly Read Books

\begin{tabular}{|c|c|c|c|c|c|c|c|c|c|c|c|c|c|}
\hline \multicolumn{14}{|c|}{$\begin{array}{l}\text { BADAN PERPUSTAKAAN DAN KEARSIPAN DAERAH } \\
\text { Jl. Kawaluyaan Indah II no. } 4 \text { BANDUNG }\end{array}$} \\
\hline & uyaan Ind & lah II no. 4 & BANDUNG & ( & & & & & & & & & \\
\hline \multicolumn{13}{|c|}{ STATISTIK BULANAN BUKU YANG DIBACA } & \\
\hline & & & & & & TAHUN : & 015 & & & & & & \\
\hline \multicolumn{14}{|c|}{ RUANG LAYANAN } \\
\hline \multirow{3}{*}{ GOL } & & & & & & & & & & & & & \\
\hline & \multicolumn{12}{|c|}{ Bulan } & \multirow{2}{*}{ JUMLAH } \\
\hline & Januari & Februari & Maret & April & Mei & Junī & Juli & Agustus & September & Oktober & November & per 14 Des & \\
\hline 000 & 194 & 298 & 542 & 558 & 437 & 347 & 356 & 328 & 356 & 354 & 114 & 33 & 3917 \\
\hline 100 & 202 & 138 & 540 & 322 & 369 & 319 & 259 & 194 & 220 & 219 & 96 & 33 & 2911 \\
\hline 200 & 241 & 284 & 369 & 313 & 207 & 234 & 169 & 241 & 209 & 174 & 505 & 205 & 3151 \\
\hline 300 & 259 & 240 & 299 & 258 & 205 & 199 & 177 & 233 & 213 & 214 & 390 & 163 & 2850 \\
\hline 400 & 308 & 252 & 282 & 237 & 247 & 149 & 180 & 187 & 264 & 254 & 116 & 42 & 2518 \\
\hline 500 & 406 & 251 & 296 & 213 & 210 & 191 & 163 & 220 & 241 & 195 & 448 & 205 & 3039 \\
\hline 600 & 517 & 247 & 300 & 226 & 157 & 211 & 134 & 206 & 267 & 118 & 119 & 51 & 2553 \\
\hline 700 & 578 & 223 & 306 & 266 & 170 & 229 & 171 & 224 & 205 & 130 & 723 & 293 & 3518 \\
\hline 800 & 967 & 200 & 270 & 260 & 246 & 222 & 172 & 263 & 207 & 134 & 858 & 336 & 4135 \\
\hline 900 & 137 & 161 & 284 & 339 & 325 & 237 & 199 & 247 & 166 & 145 & 115 & 39 & 2394 \\
\hline JUMLAH & 3809 & 2294 & 3488 & 2992 & 2573 & 2338 & 1980 & 2343 & 2348 & 1937 & 3484 & 1400 & 30986 \\
\hline
\end{tabular}

Source: West Java Regional Library and Archives Agency, 2015

The books in the library consist of two types of books: fiction and non-fiction books. Based on the above statistics, it explains that the collection most frequently accessed and read by children in 2015 was 800 collections, which was literature. Among various collections owned by West Java Regional Library and Archives Agency, comic was the most frequently accessed collection by the children.

This finding is strengthened by a research conducted Purwatiningsih (2010), which found that it was only a small collection that was used and borrowed with the average use of $10.48 \%$. In other words, it was still a small collection that is borrowed by children. This is also happening in the children reading room in West Java Regional Library and Archives Agency. Very few collections are used by children; the children collection has not been maximally utilized and the constantly accessed collection is only a particular collection.

"For the highest percentage of reading books, which is often borrowed and read, it is only that collection, yes only collection 800. Not with others."

The collection frequently accessed or utilized by children in West Java Regional Library and Archives Agency is collection 800 namely literature. After filling the visit list of children reading room service, the children immediately run to collection 800 shelves, which is literature, and pick the book right away and read it on the table.

"I really like to read Naruto or sort of fairy tale since those kinds of reading have many pictures and are colorful. Then, there are meanings or messages in each story and I often get inspiration after reading the comic."

Based on the explanation of Afred Schutz (cited in Kuswarno, 2009) regarding the goals of phenomenology, phenomenology functions to construct the "real" world of human life in the form of direct experience. Furthermore, Schutz explains the categorization of one's action based on two phases: In Order to Move Motivate (Um-zu-Motiv), which means a motive referred to the action in the future, and Because Motives (Weil Motiv) actions, which means a motive referred to the past. This is related to what has been done by the children when reading literary works such as novel, legend and comic. This action certainly has particular reasons such as having reading as a hobby since childhood and making reading as a hobby until the present time. These are motives in the form of a person's consistency in his/her hobby. A book provides meaning and inspiration when the reading is finished, which becomes a force and knowledge to apply in everyday life. The motive of one having reading as a hobby is due to his/her desire to become an intelligent individual. Due to that desire, it will impact the future of his/her life that if he/she diligently done reading, he/she will be an intelligent person later.

Based on the statistical data that has been previously shown, the borrowing of the collection was more dominant in the subject of literature. Then, based on the children's statement, they gain the inspiration and meaning after reading the book from collection 800 that is literature. This is in accordance with Afred Schultz's explanation (Kuswarno, 2009); one has a motive that refers to action in the future, where the actions taken by a person must have a predetermined purpose; there are actions that refer to the past, which the action performed by someone must have a reason from the past.

Seeing the phenomenon of children librarian in utilizing the collection in the reading room of West Java Regional Library and Archives Agency, the authors are interested to study the utilization motive of collection in the children reading room of West Java Regional Library and Archives Agency based on the motive of past experience and future experience. Based on the findings in the field, the purpose of this research is: 
1) To find out how the utilization motive of the collection in the children reading room West Java Regional Library and Archives Agency that refers to the action in the future; and

2) To find out how the utilization motive of the collection in the children reading room West Java Regional Library and Archives Agency that refers to the action in the past.

The significance of research is theoretically used as the reference for the development of science, especially in the field of children literature collection. This research is expected to provide a significant contribution practically for children to access or utilize all kinds of collection available in the library, in this case West Java Regional Library and Archives Agency. This research also expects the Library and Archives to continue to innovate in improving the quality of service for children, so the collection utilization can be accessed evenly. Moreover, this research serves to increase the repertoire of science in the library study particularly for the authors and generally for various parties who concern directly or indirectly. The authors significantly expect that this research can be a source and reference for other researchers who want to further research on the use of children literature collection in West Java Regional Library and Archive Agency and other libraries.

The theory used in this study is phenomenology. Phenomenology theory is: example, if researchers attempt to describe the phenomenon of an environment according to their own views. Phenomenology is the actual experience by way of data about the reality that being studied. The tendency of word phemenon is the origin of the term phenomenology that is formed, and can be interpreted as a display of objects, conditions or invented, according to each perception (Littlejohn, 2002, p. 184). Phenomenology is the study of the way in which the phenomena of conscious things appear to us, and the most fundamental way of their emergence is as a stream of sensory experiences related to those we receive through the five senses.

Alfred Schutz (in Kuswarno, 2009, p. 110) explains that the task of phenomenology is to construct the "real" world of human life in the form that experienced by themselves. Furthermore Kuswarno (2009, p. 110) suggests the reality of the world is intersubjective, meaning that members of society are sharing a basic perception of a world that they internalize through socialization and allowing them to interact or communicate. Schutz (Kuswarno, 2009) explains the grouping of one's actions based on 2 phases i.e.,

a. In order to move, motivate $(U m-z u$-Motiv), a motive that will refer to the action in the future, whereas the actions taken by someone must have a predetermined objective. This motive is used by humans to be made a foothold by a person to do something that aims for achieving results.

b. Because motives (Weil Motiv), an action that refer to the past. Where the actions performed by someone must have a reason of the past when he did it. This motive identifies the past as well as analyzes it to how much it contributes to the next action.

\section{METHODS}

The research method used in this research was the method with qualitative approach. The type of research used in this study was the study of phenomenology. The informants who made the subject of this study consisted of children's patron and children's reading room service librarian. Researchers applied the technique of purposive sampling in cases determining the informant.

Table 1.2

Research Informant

\begin{tabular}{lll}
\hline Informant & Children Patron & \\
\hline & & \\
Keys Informant & Children Service & Librarian \\
& BAPUSIPDA JABAR & \\
\hline
\end{tabular}

The data collected in this study, comprehend various stages, i.e: participant observation and in-depth interview, in-depth interviews require in-depth information to obtain information point coming from informants. This interview is aimed at child's patron and children's reading room service librarian. Data analysis in this research is done by following the procedure on the steps as stated by Sugiyono $(2015$, p. 91) that is "data reduction, data display, conclusion and verification." Examination of the validity of the data used in this study is triangulation. Triangulation, which is checking the truth of the data obtained from various sources in various ways and various times.

\section{FINDING AND DISCUSSION}

This study examined the utilization motives of collection in children's reading room institutions of Library and Archives of West Java (BAPUSIPDA). The research data was collected to five informants, the child's patron who used the collection in the children's reading room BAPUSPDA. Research data acquisition is done by direct observation or participant observation about activities conducted by children who utilize children's reading room service at Library 
and Archives of West Java, and an open interview conducted by researchers to informant, which have been chosen by researchers based on criteria that is children who are in the elementary school grade using the collection in the children's reading room BAPUSIPDA. Here's the profile of the informant:

Table 1.3

Informan profile

\begin{tabular}{lllll}
\hline No & Initial & Age y.o. & Grade/profession & Education background \\
\hline $\mathbf{1}$ & ER & 12 y.o. & 6th & Elementary School \\
\hline $\mathbf{2}$ & FNI & 12 y.o. & 6 th & Elementary School \\
\hline $\mathbf{3}$ & HSH & 12 y.o. & 6 th & Elementary School \\
\hline $\mathbf{4}$ & DTC & 12 y.o. & 6 th & Elementary School \\
\hline $\mathbf{5}$ & TNF & 12 y.o. & 6 th & Elementary School \\
\hline
\end{tabular}

In general, the child's patron who likes the collection of collectibles fiction and non-fiction contained in the children's reading room BAPUSIPDA. The types of non-fiction books favored by the child's readers are textbooks which are appropriate to their subjects such as math books, Indonesian books, KDP books, RPALs, RPULs, and other textbooks. In general, the child's patron utilizes this non-fiction collection for school needs such as learning and doing homework. Besides for the collection of non-fiction, the collection of fiction is a favorite for child's patron as well. A collection of fiction books favored by child's patron have usually been a book with the picture and has color variations. Popular fiction books are like Comics, and folklore.

This study refers to the phenomonology theory of Alfred Schutz (Kuswarno, 2009, p. 110) which reveals that phenomenology constructs the "real" human world in their own natural form, Schutz also classifies one's action based on two phases, i.e.: In order to move, motivate (Um-zu-motiv) is a motive that refers to the actions in the future, and the second phase is because motives (Weil Motiv) are acts that refer to the past. This study divides the results that refer to two phases of a person's actions.

\section{In order to move motivate (Um-zu-Motiv)}

Utilization of collections in the children's reading room Library and Archives of West Java by a patron who is a child in an elementary school grade level. Active activities undertaken by the child patron in utilizing the child's reading room service is by reading the library collection frequently and borrowed the collections to bring it home. The motive for the use of this collection is done by the child's reader with the aim that the existing knowledge in the collection can influence his intellectual power so the librarian can be an intelligent student and do the school tasks given by his teacher, it is conveyed by ER, "I want to be a smart kid, if I read a book, so my knowledge increase ". This is related to the cognitive needs of children in increasing knowledge. Katc, Gurevitch, and Haas (Pawit, 2009, p. 338) explains that cognitive needs are necessarily closely related to the need to strengthen or to gain information, knowledge, and one's understanding of their surroundings so that new experiences in life are gained. In addition, the use of collections in the children's reading room is also based on the need for school exams, it is conveyed by TNF, "I often borrow books for studying to get me ready facing my midtest, Daily test and national exam (UN) preparation". Besides to adding insight about science, the use of children's reading room collection at the Library and Archives of West Java as well as reference materials for children when the child will face the exam given by the school.

In addition to the use of collections in the children's reading room as a form of implementation of the cognitive needs fulfillment, the attraction of the book collections is a vital factor that affects children to read books as well. The FNI revealed, "I like fiction books, like folklore, fairy tales, and comics". This type of collection becomes the motive for a child to read, the children basically like light-loaded books that do not require high thinking/reasoning power so that the messages contained in the book can be understood by the child wholly, besides that the child has a high imagination in interpreting something, through the collections like fairy tales, comics, illustrated stories, and other collections in a child's imagination.

The values contained in the children's reading in the children's reading room become one of the motives for the reader of children reading the book. In general, the values contained in the reading of children are the books that have moral value. The moral value contained in the book is an inspiration and example for children in their social life. ER said, "the books here are inspiring a lot, so we can imitate the good things and not be affected by the bad things". Nurgiyantoro $(2005$, p. 6) reveals that children's literature is emotionally, psychologically responsive and understood by children, and it is generally starts from concrete and imaginative facts.

The characters in the storybook that are constructed by the author of the book also become role models for children in life, they take the traits and behaviors within the character, this is conveyed by the FNI, "I do not like malin kundang, he is godless, because he was godless himself changing into stone, I do not want to fight to my parents and 
rebellious to the parents who gave birth to us ". In addition HSH also said, "I love Naruto, he saves people, he is brave, never give up, discipline, and superb." When a child admires the characters in the story, then the child will be curious about the stories of the character's journey, this is the attraction of a book that then affects the child's favorite in reading. The child will take each of the characters, attitudes, and experiences of the character in the story, Huck (1987) explains that the children will feel how to endure hardship and take risks, will also be challenged to dreaming various of dreams also contemplate and express various problems about himself.

\section{Because motives (Weil Motiv)}

The selection of children's reading room as a referral service for child readers is based on the completeness of the book's collection in the children's reading room, so it makes the child readers to have more choices about the collection they need, as stated by FIN. "I often come to the library, almost every day, because there are a lot of book's collections in this library. Thus, I won't be confused to choose the book that I want". Completeness of book collection becomes a factor that influences children to read books in the children's reading room. Handoko (Handayani, 2007, p.28) describes the factors that affect the use of library materials, which are the completeness of book collection that could be used by users, as well as librarian's skills.

The utilization of children's collection in Library and Archives of West Java is also influenced by a user's hobby, a reading hobby that has been taught by the user's parents at home, as stated by TNF, "I have a reading habit since I was a kid, which has become my hobby. The habit is taught by my mom. Because there are a lot of books in this library, I continue the habit". The availability of many collections becomes a motive for children to use library collections, based on their passion. With the availability of many book's collections, children can channel their hobby to read. Children will have many chances to read many kinds of books rather than having to buy books outside or reread the same book. Designs of book's collection also become a supporting factor for children to read books, as conveyed by DTC, "I love reading illustrated and colorful books. I won't read heavily text-books". Colors and pictures become things required in a good book for toddlers and early adolescence children, because colors and images provide an attractive appearance to the readers, and also the messages in the books can be easily absorbed by the children.

Not only the book collection that could appeal children into using the reading room, but also the condition of the reading room itself, as explained by ER, "I can read books as many as I want in this library because the place is nice and cool, for there are air conditioners here. I can comfortably laying down while reading". The comfortable condition of reading room can make people, especially children who hate uncomfortable condition of a room, to stay for long in the reading room. With the presence of facilities that can be used to have a rest, or even sleep, it can make children to have a choice to take a break when reading a book.

\section{CONCLUSION AND RECOMMENDATION}

Based on the results and discussion of the above research, it can be concluded that research on the motive utilization of children's literature collection in children's reading room Library and Archives of West Java is based on In order to move motivate or motive for the future, and because motives or motives of the past.

\section{In order to move motivate (Um-zu-Motiv)}

Motive utilization of children's collections in the children's reading room in Library and Archives of West Java, which refers to the action to come is to increase the science of children, with the desire of children to read books in children's reading room will affect the intellectual power and cognitive ability. Utilization of the collection of children's literature books were used by children as a means of child referrals in doing the task, and as material for children facing exams at school. Motive utilization of children's collection in children's reading room is also based on the collection factor that is on the type of collection that is read, child readers are more fond of reading lightly charged readings so that the messages contained in the collection are easy to be understood by children. The values contained in the reading are also factors that encourage the child readers to make use of the collections in the Children's reading room, the children will make inspiring books an example for them in social life. In addition, the figures contained in non-fiction children's books are also the motive for children in reading the collection of children's literature books, non-fiction children's books, generally have a character that later became a role model for children in the attitude and act in reality.

\section{Because motives (Weil Motiv)}

Motive utilization of children's collections in the children's reading room in Library and Archives of West Java that refers to the actions, which refer to the past, is based on the completeness of the collection contained in the children's reading room. Therefore, the completeness of book collection makes children to prefer the library as a place to meet their needs. Another motive utilization of children's literature collection is influenced by the children's hobby of reading, so that children will be able to actualize their hobby to read. The motive for the collection of children literature books based on the collection factor is the design, the child prefers books that have many pictures and has color variations, so that children prefer reading and the easiness to absorb the values contained in the collection.

Here are the researcher's recommendation for West Java Regional Library and Archives: 
1. Increase the number of fiction and non-fiction children's book so that more reading material can be read by children.

2. Increase the facilities in the reading room for children so that children feel more comfortable reading the books.

3. Increasing the promotion activities of children's reading room so more and more users are coming

4. Conducting children's literacy activities so that children get closer to the book.

5. Increasing the number of librarians who accompany children while reading.

\section{References}

Handayani, et al. (2007). Studi korelasi motivasi pengguna dan pemanfaatan koleksi CDROM di UPT Pusat Perpustakaan UII Yogyakarta. Jurnal Berkala Ilmu Perpustakaan dan Informasi, 3(7), 25-33

Huck, Charlutte, et al. (1987). Children literature in elementary school. Chicago: Rand Mc Nally Collage Publishing Company.

Kuswarno, E. (2009). Fenomenologi. Bandung: Widya Padjadjaran

Nurgiyantoro, B. (2005). Sastra Anak: Pengantar Pemahaman Dunia Anak. Yogyakarta: Universitas Gajah Mada.

Purwatiningsih, A. (2010). Evaluasi keterpakaian koleksi perpustakaan di SMKN 1 KALASAN. [skripsi]. Yogyakarta: UIN Yogyakarta.

Sugiyono. (2015). Memahami penelitian kualitatif. Bandung: Alfabeta.

Yusuf, M. Pawit, et al. (2009). Ilmu informasi, komunikasi \& kepustakaan. Jakarta: Bumi Aksara 